\title{
PENGARUH PENGGUNAAN ENDORSER SELEBRITI NASIONAL DAN ENDORSER SELEBRITI GLOBAL DALAM IKLAN PADA SIKAP KONSUMEN
}

\author{
Cempaka Paramita \\ Fakultas Ekonomi dan Bisnis Universitas Jember \\ cempaka.feb@unej.ac.id
}

\begin{abstract}
This study examines the differential effect of using national celebrity endorser versus global celebrity endorser in an advertisement on consumer attitude. The experimental research design was conducted on a total of 100 participants. Fictitious print advertisements featuring national celebrity and global celebrity as endorsers for the same product were used as the treatment. One-way Analysis of Variance (ANOVA) was used for data analysis. The findings of the study revealed that celebrity endorserment is effective for advertisement as part of marketing communication, where national celebrity endorser has more positive effect on consumer's attitude toward the advertisement than global celebrity endorser. However, both celebrity endorsers have no significant effect on consumer attitude toward the brand and purchase intention.
\end{abstract}

Keywords: celebrity endorser, advertisement, consumer attitude, experimental design.

\begin{abstract}
Penelitian ini menguji perbedaan pengaruh penggunaan selebriti nasional dan selebriti global dalam iklan pada sikap konsumen. Metode penelitian yang digunakan adalah eksperimen dengan sampel berjumlah 100 partisipan. Penelitian ini menggunakan iklan cetak fiktif yang menampilkan selebriti nasional dan selebriti global sebagai sampel untuk produk yang sama sebagai treatment pada eksperimen. Data dianalisis menggunakan ANOVA. Hasil penelitian menunjukkan bahwa endorsement menggunakan selebriti dalam iklan merupakan metode komunikasi pemasaran yang efektif, yang mana penggunaan selebriti nasional lebih efektif daripada penggunaan selebriti global dalam mempengaruhi sikap konsumen. Namun, penggunaan selebriti global dan nasional sebagai endorser dalam iklan tidak berpengaruh signifikan pada sikap konsumen terhadap merek dan niat untuk membeli.
\end{abstract}

Kata Kunci: endorser selebriti, iklan, sikap konsumen, desain eksperimen

\section{Pendahuluan}

Setiap harinya konsumen terpapar oleh berbagai macam pesan iklan di berbagai media. Namun, tidak semua iklan bisa diingat dan direspon dengan baik oleh konsumen karena mereka memiliki keterbatasan memori dan kemampuan dalam menangkap pesan iklan yang disampaikan. Biasanya, konsumen hanya mengingat iklan yang mereka anggap menarik baik dari segi tampilan visual, penggunaan musik (pada iklan televisi dan radio), penggunaan bahasa, atau dari segi sumber penyampai pesan. Efektivitas suatu iklan tergantung pada kreativitas pemasar dalam merancang format iklan, seperti yang diungkapkan oleh Alsmadi (2006) dimana strategi pemasaran modern dari kebanyakan bisnis sangat bergantung pada iklan yang kreatif untuk mempromosikan produk mereka ke 
konsumen sasaran. Salah satu strategi periklanan yang banyak digunakan oleh pemasar untuk mempengaruhi konsumen adalah dengan menggunakan figur publik dari kalangan selebriti. Selebriti adalah individu yang terkenal atau memiliki pengaruh terutama di industri hiburan atau di dunia bisnis (Nelson, 2010), yang mendapatkan pengakuan publik oleh sejumlah besar kelompok orang (Hakimi et al. 2011) karena prestasi atau kesuksesannya di bidang tertentu (James, 2004 dalam Ranjbarian et al. 2010) seperti atlit, entertainer, pembaca berita, politisi, aktor, pekerja seni, pemimpin komunitas, hingga tokoh militer (Bhushan, 2007 dalam Jain et al. 2010; McCracken, 1989). Berdasarkan wilayah geografis, Jain et al. (2010) mengklasifikasikan selebriti dalam 3 kategori, yaitu: selebriti global (dikenal di lebih dari satu negara), selebriti nasional (pengakuannya terbatas pada satu negara tertentu), dan selebriti regional (dikenal dan diapresiasi oleh wilayah regional tertentu dari suatu negara tapi tidak dikenal di wilayah regional lainnya.

Studi eksperimen yang dilakukan oleh Friedman et al. (1976) berkenaan dengan penggunaan 4 (empat) jenis endorser dalam iklan (selebriti, mahasiwa, ahli profesional, dan pimpinan perusahaan) menyimpulkan bahwa penggunaan endorser dalam periklanan akan lebih bermanfaat untuk mempromosikan produk dibandingkan dengan penggunaan iklan tanpa adanya endorser. Banyak penelitian yang mengemukakan bahwa penggunaan figur publik dari kalangan selebriti lebih efektif daripada endorser lainnya seperti para ahli atau profesional, manajer perusahaan, atau konsumen biasa (Friedman dan Friedman, 1979, dalam Seno dan Lukas, 2007). Beberapa penelitian menyatakan bahwa penggunaan endorser selebriti dalam iklan berpengaruh positif pada sikap konsumen terhadap iklan, sikap konsumen terhadap merek, dan niat beli (Liu et al. 2007; Pughazhendi et al. 2011). Namun, beberapa penelitian lainnya mengemukakan bahwa endorser selebriti dalam iklan hanya efektif mempengaruhi sikap terhdap iklan dan sikap terhadap merek, tapi tidak efektif mempengaruhi niat beli konsumen (Alsmadi, 2006; Jain et al. 2010; O'Mahony dan Meenaghan, 1997/1998; Ranjbarian et al. 2010). Hasil penelusuran secara online pada situs-situs penyedia jurnal tentang penelitian selebriti sebagai endorser dalam iklan (EBSCO, JSTOR, Springerlink, Emeraldinsight, Google Schoolar, ABI Inform, dan sebagainya), menunjukkan bahwa masih terbatas penelitian yang menguji tentang perbedaan pengaruh pengunaan endorser selebriti dalam iklan pada sikap konsumen berdasarkan lokasi geografis (nasional, regional, atau global). Penelitian oleh Jain et al. (2010) membuktikan bahwa penggunaan selebriti sebagai endorser 
dalam iklan efektif bagi program komunikasi pemasaran, dan ternyata selebriti nasional lebih bisa mempengaruhi sikap konsumen terhadap iklan dan merek secara positif jika dibandingkan dengan selebriti regional.

Sikap terhadap iklan merupakan suatu learned tendency untuk merespon dalam suatu pendekatan yang diinginkan atau tidak diinginkan secara konsisten terhadap iklan secara umum, yang menunjukkan apakah konsumen menyukai atau tidak menyukai iklan tersebut (Ranjbarian et al. 2010). Pada umumnya, para peneliti berpendapat bahwa sikap terhadap iklan adalah komponen afektif yang merepresentasikan perasaan konsumen terhadap iklan, apakah mereka menyukai atau tidak menyukai iklan tersebut, yang merupakan pengaruh yang memediasi sikap terhadap merek dan niat beli (Mitchell dan Olson, 1981 dalam MacKenzie et al. 1986). Selain sikap yang positif atau menyenangkan terhadap merek, tujuan dari komunikasi pemasaran adalah agar konsumen memiliki niat untuk membeli merek tersebut (Peter dan Olson, 2001:134). Berkaitan dengan periklanan, niat beli menunjukkan keinginan konsumen untuk membeli produk setelah terpapar oleh iklan. Iklan yang menarik dari sisi isi pesan, cara penyampaian pesan, dan sumber pesan, akan menimbulkan perhatian konsumen dan berpengaruh positif pada sikap terhadap iklan. Sikap positif terhadap iklan akan menuntun pada sikap positif terhadap merek yang akhirnya bisa menimbulkan niat beli konsumen terhadap produk atau merek yang diiklankan tersebut.

Berdasarkan penelitian yang dilakukan oleh Mehta (1994), proses penerimaan iklan bagi seorang konsumen dalam model Advertising Response Modelling (ARM) bisa dilihat dari dua proses, yaitu: sentral (dari sisi produk dan merek) dan peripheral (dari sisi iklan dan model iklan). Dalam penelitian ini, model iklan yang diteliti adalah menggunakan endorser selebriti nasional dan endorser selebriti global. Respon konsumen terhadap pendekatan sentral dan peripheral diproses sebagai berikut: iklan yang efektif akan menarik perhatian dan konsumen akan memproses informasi yang diperoleh melalui rute sentral dan peripheral. Dari proses informasi sentral, maka produk atau merek yang ada pada iklan akan mempengaruhi sikap konsumen terhadap iklan, sedangkan pada rute peripheral, penggunaan endorser sebagai sumber atau model iklan akan mempengaruhi sikap terhadap iklan serta akan menimbulkan sikap terhadap merek yang diiklankan tersebut.

Penggunaan endorser selebriti nasional dinilai lebih tepat daripada menggunakan endorser selebriti global, khususnya untuk iklan yang ditujukan hanya 
pada satu wilayah negara tertentu. Hal ini dikarenakan selebriti nasional lebih dikenal oleh masyarakat di negara tersebut. Beberapa penelitian sebelumnya membuktikan bahwa penggunaan endorser selebriti efektif dalam mempengaruhi sikap konsumen terhadap iklan (Liu et al. 2007; Pughazhendi et al. 2011). Berdasarkan penjelasan tersebut, maka peneliti merumuskan hipotesis pertama sebagai berikut:

a. $\mathrm{H} 1$ : Iklan yang menggunakan endorserselebriti nasional lebih berpengaruh secara positif pada sikap konsumen terhadap iklan dibandingkan dengan iklan yang menggunakan endorser selebriti global.

Sikap positif konsumen terhadap iklan dengan endorser selebriti diharapkan dapat berpengaruh positif pula pada sikap terhadap merek yang diiklankan oleh selebriti tersebut. Berdasarkan penjelasan tersebut, maka hipotesis kedua yang diajukan dalam penelitian ini adalah:

b. H2: Iklan yang menggunakan endorser selebriti nasional lebih berpengaruh secara positif pada sikap konsumen terhadap merek dibandingkan dengan iklan yang menggunakan endorser selebriti global.

Penggunaan endorser selebriti yang tepat dalam iklan diharapkan bisa mempengaruhi sikap positif konsumen terhadap iklan yang akan memberi efek positif pula pada sikap konsumen terhadap merek yang diiklankan, yang akhirnya akan berpengaruh pada niat konsumen untuk membeli produk atau merek yang diiklankan tersebut.

c. H3: Iklan yang menggunakan endorserselebriti nasional lebih berpengaruh secara positif pada niat beli konsumen dibandingkan dengan iklan yang menggunakan endorser selebriti global.

Model konseptual dari penelitian ini dimodifikasi dari model penelitian yang diajukan oleh Jain et al. (2010), sebagai berikut:

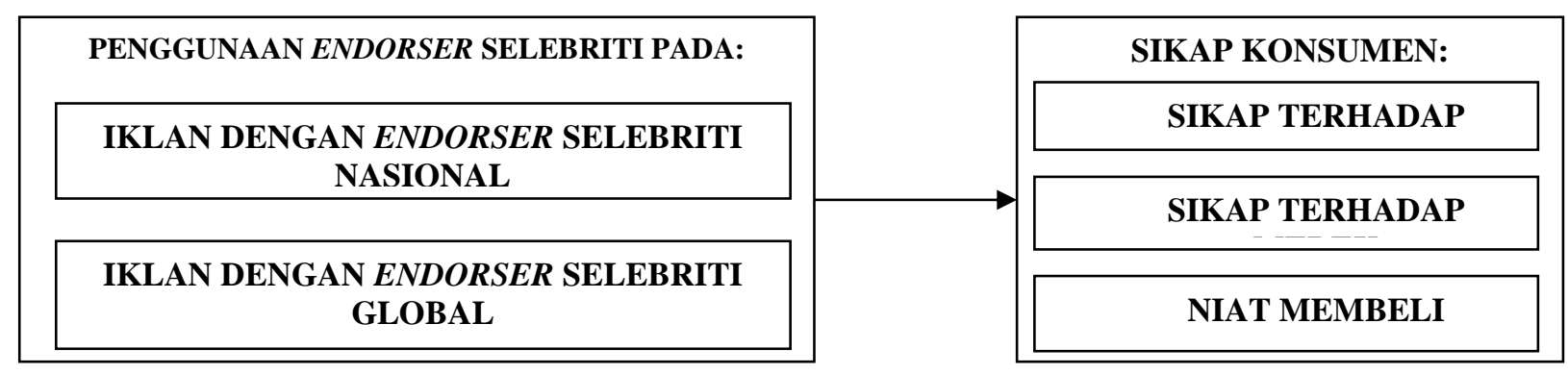

Gambar 1. Kerangka Konseptual Penelitian

Berdasarkan latar belakang yang telah dipaparkan sebelumnya, maka penelitian ini bertujuan untuk menguji perbedaan pengaruh selebriti sebagai endorser 
dalam iklan berdasarkan jangkauan geografis, yaitu dalam skala nasional dan global, untuk mengidentifikasi apakah terdapat perbedaan pengaruh antara penggunaan selebriti nasional dan selebriti global sebagai endorser dalam iklan pada sikap konsumen terhadap iklan, sikap konsumen terhadap merek, dan niat konsumen untuk membeli produk atau merek yang diiklankan tersebut. Dalam penelitian ini, terdapat tiga variabel dependen yang berkenaan dengan sikap konsumen, yaitu sikap terhadap iklan, sikap terhadap merek, dan niat beli. Menurut Assael (2001:283-285), sikap terdiri dari tiga komponen, yaitu: kognitif (berkaitan dengan pemikiran yang menunjukkan kepercayaan yang dimiliki konsumen terhadap suatu merek), kemudian afektif (berkaitan dengan perasaan yang merepresentasikan evaluasi keseluruhan konsumen terhadap merek), dan konatif (berkaitan dengan perilaku yang menunjukkan kecenderungan untuk bertindak terhadap suatu objek yang biasanya diukur sebagai niat untuk membeli).

\section{Metodologi}

\section{Desain Penelitian}

Penelitian ini menggunakan metode eksperimen untuk mengetahui hubungan sebab akibat, yang merupakan jenis penelitian dimana peneliti dapat memanipulasi satu atau lebih variabel independen (experimental) dan kemudian mengukur efek dari manipulasi tersebut terhadap variabel dependen (Aaker et al. 2011:304). Penelitian ini menggunakan eksperimen laboratorium between subject karena pada kedua level perlakuan yang diberikan dalam eksperimen, tiap kelompok eksperimen hanya mendapatkan satu level perlakuan saja, yaitu iklan dengan endorserselebriti nasional (kelompok eksperimen 1) atau iklan dengan endorser selebriti global (kelompok eksperimen 2). Jenis desain eksperimen yang digunakan yaitu statistical completely randomized design, dimana perlakuan yang diberikan pada partisipan penelitian didasarkan pada randomisasi (Aaker et al. 2011:316-317). Dalam penelitian ini tidak digunakan kelompok kontrol, karena masing-masing kelompok perlakuan merupakan kelompok kontrol bagi kelompok lainya (Aaker et al. 2011:317). Peneliti melakukan eksperimen untuk mengetahui perbedaan pengaruh antara iklan yang menggunakan endorser selebriti nasional dan iklan dengan endorser selebriti global pada sikap konsumen terhadap iklan, sikap konsumen terhadap merek yang diiklankan, dan niat konsumen untuk membeli merek tersebut.

Pada satistical completely randomized design, partisipan penelitian dikelompokkan dalam dua kelompok secara terpisah yang masing-masing diberi 
perlakuan salah satu dari dua format iklan cetak yang digunakan sebagai sampel iklan. Seorang subjek yang sudah diperlihatkan iklan dengan endorser selebriti nasional, tidak akan diperlihatkan dengan iklan dengan endorser selebriti global karena hal tersebut akan memberikan bias efek urutan. Desain penelitian dinotasikan sebagai berikut:

\section{$E G_{1} R\left(X_{1} O_{1}\right)$}

\section{$E G_{2} R\left(X_{2} \mathrm{O}_{2}\right)$}

Keterangan: $E_{1}$ adalah experimental group 1, sedangkan $E_{2}$ adalah experimental group 2. $\mathrm{R}$ adalah notasi randomization (subjek yang ditempatkan secara random atau acak). $X_{1}$ adalah exposure 1 (subjek yang diperlihatkan perlakuan 1), sedangkan $X_{2}$ adalah exposure 2 (subjek yang diperlihatkan perlakuan 2). $\mathrm{O}_{1}$ adalah observasi formal atau measurement 1 (respon subjek terhadap perlakuan yang diukur dengan memberikan kuesioner yang diisi sendiri setelah diberikan perlakuan 1), $\mathrm{O}_{2}$ adalah observasi formal atau measurement 2 (respon subjek terhadap perlakuan yang diukur dengan memberikan kuesioner yang diisi sendiri setelah diberikan perlakuan 2).

\section{Pengumpulan Data}

Pengumpulan data dilakukan dengan menggunakan kuesioner sebagai alat pengukur sikap. Karena penelitian ini menggunakan dua level perlakuan, maka digunakan satu kuesioner untuk dua versi iklan yang berisi pernyataan-pernyataan untuk mengetahui opini partisipan tentang sikap terhadap iklan, sikap terhadap merek, dan niat beli setelah mereka melihat iklan cetak dengan endorser selebriti nasional dan endorser selebriti global. Unit sampel yang digunakan dalam penelitian ini adalah individu yang diwakili oleh mahasiswa. Sampel diambil dengan teknik purposive judgment sampling (non-probabilitas) karena peneliti menentukan kriteria tertentu dalam pemilihan sampel yang akan dijadikan partisipan dalam penelitian. Rules of thumb dalam menentukan ukuran sampel untuk sebagian besar penelitian pada umumnya menggunakan ukuran sampel antara 30-500, dimana untuk penelitian eksperimen jumlah ukuran sampel 10-20 sudah cukup baik (Roscoe, 1975, dalam Sekaran dan Bougie, 2010:296-297). Partisipan penelitian dibagi dalam dua kelompok eksperimen. Kelompok eksperimen pertama diberi perlakuan berupa iklan cetak dengan endorser selebriti nasional, dan kelompok kedua diberi perlakuan berupa iklan cetak dengan endorser selebriti global. 


\section{Sampel Iklan}

Sampel iklan yang digunakan adalah dua buah iklan cetak berwarna untuk produk yang sama, dalam kategori produk dengan tingkat keterlibatan yang rendah, khususnya untuk consumer goods. Pemilihan iklan cetak sebagai sampel iklan karena tidak memungkinkan untuk membuat iklan televisi atau iklan dengan format video berkenaan dengan efisiensi biaya. Sesuai dengan elaboration likelihood model (Petty et al. 1983), ARM (Mehta, 1994), dan hasil studi oleh Jain et al. (2010), penggunaan endorser dalam iklan, terutama selebriti, lebih tepat untuk iklan dengan kategori produk dengan tingkat keterlibatan yang rendah. Dian Sastro dipilih sebagai endorser selebriti nasional (dikenal dalam skala nasional, yaitu di negara Indonesia) dan Anne Hathaway dipilih sebagai endorser selebriti global (dikenal di banyak negara) yang ditampilkan dalam sampel iklan. Selain berdasarkan lokasi geografis, alasan pemilihan kedua selebriti tersebut adalah karena latar belakang profesi yang sama yaitu sebagai aktris dan model, dengan daya tarik fisik dan kepribadian yang menarik, memiliki citra yang cukup baik di masyarakat, dan masih mempertahankan eksistensinya hingga saat ini. Kedua selebriti tersebut memiliki kredibilitas yang baik sebagai endorser dalam berbagai iklan, dan keduanya belum pernah menjadi endorser untuk iklan produk minuman kombinasi jus buah dan sayur, sehingga diharapkan penggunaan kedua selebriti tersebut sebagai endorser tidak memberikan efek bias karena konsumen telah memiliki sikap awal tertentu terhadap mereka dan produk yang di-endorse jika sebelumnya mereka pernah menjadi endorser untuk produk sejenis.

Produk yang digunakan adalah produk minuman jus buah dan sayur yang diberi merek fiktif untuk mencegah pengaruh pengalaman pernah menggunakan merek tertentu serta menghindari biasnya respon karena ada sikap awal subjek terhadap merek tertentu atau meminimalisir pengaruh dari brand familiarity (Till dan Busler, 1998). Produk tersebut digolongkan sebagai produk dengan tingkat keterlibatan yang rendah karena tidak mahal dari segi harga sesuai segmen konsumen yang dituju yaitu pria dan wanita usia remaja dan dewasa yang dalam penelitian ini mewakili karakteristik partisipan yang diambil untuk eksperimen, konsumen tidak membutuhkan pencarian informasi yang aktif tentang produk karena resiko produk yang rendah, serta dengan mengkonsumsi produk tersebut tidak relevan mencerminkan kepribadian konsumen (Assael, 2001:146). 


\section{Cek Manipulasi}

Sebelum melakukan penelitian eksperimen yang sesungguhnya, peneliti terlebih dahulu melakukan cek manipulasi untuk mengetahui apakah perlakuan yang dilakukan tepat atau tidak, untuk memastikan bahwa subjek mampu mengenali dan membedakan selebriti nasional dan selebriti global yang digunakan sebagai endorser dalam iklan. Jumlah sampel dalam cek manipulasi ini adalah 52 orang yang berbeda dengan sampel yang digunakan dalam ekperimen yang sesungguhnya. Hasil dari cek manipulasi menunjukkan bahwa pelakuan yang diberikan, yaitu iklan dengan endorser selebriti nasional dan iklan dengan endorser selebriti global, sudah tepat. Hasil 2-sample t-test menunjukkan adanya perbedaan nilai mean yang signifikan untuk kedua jenis iklan tersebut, yang berarti bahwa partisipan bisa mengidentifikasi endorser selebriti nasional atau global yang digunakan dalam iklan, dan bisa membedakan mereka berdasarkan lokasi geografis, nasional atau global. Nilai mean untuk iklan dengan endorser selebriti nasional adalah 4,2692 (> 2,5) yang artinya bahwa Dian Sastro yang digunakan sebagai endorser dalam iklan tersebut bisa dikenal atau diidentifikasi oleh partisipan sebagai endoerser selebriti nasional, sedangkan nilai mean untuk iklan dengan endorser selebriti global adalah 3, 8365 (> 2,5) yang artinya bahwa Anne Hathaway juga bisa diidentifikasi oleh partisipan. Perbedaan nilai mean antara endorser selebriti nasional dan endorser selebriti global dalam iklan pada cek manipulasi juga cukup signifikan yang artinya bahwa partisipan dapat membedakan kedua endorser selebriti tersebut.

\section{Prosedur dan Instrumen Eksperimen}

Eksperimen dilakukan pada mahasiswa. Kelompok eksperimen pertama diberi perlakuan berupa iklan cetak dengan endoser selebriti nasional, dan kelompok eksperimen kedua diberi perlakuan iklan cetak dengan endorser sebebriti global. Partisipan diberi waktu 10 menit untuk membaca dan memahami sampel iklan tersebut. Setelah itu dibagikan kuesioner dan diberikan petunjuk untuk mengisi kuesioner tersebut agar partisipan dapat mengisi kuesioner dengan tepat.

Instrumen penelitian yang digunakan adalah 2 lembar iklan cetak berwarna yang terdiri dari 1 iklan yang menggunakan endorser selebriti nasional dan 1 iklan dengan endorser selebriti global untuk jenis produk yang sama. Instrumen lain yang juga digunakan adalah kuesioner untuk dua level perlakuan. Dalam kuesioner tersebut, skala pengukuran yang digunakan adalah semantic differential scales, sesuai dengan penelitian-penelitian sebelumnya (Kamins, 1990; Silvera dan Austad, 
2004), dimana keseluruhan butir-butir pernyataan dalam kuesioner meliputi variabel sikap terhadap iklan, sikap terhadap merek, dan niat beli dengan jumlah skala pengukuran dalam kuesioner adalah 1-7 (seven-point rating scales).

\section{Alat Analisis}

Dalam penelitian ini, seluruh hipotesis diuji dengan alat analisis yang sama untuk mengukur dua hal yang berbeda, yaitu menguji perbedaan pengaruh iklan yang menggunakan endorser selebriti nasional dan iklan yang menggunakan endorser selebriti global pada sikap terhadap iklan, sikap terhadap merek, dan niat beli. Alat analisis yang digunakan untuk menguji hipotesis tersebut adalah one-way analysis of variance (ANOVA) dengan tujuan untuk mengetahui hasil uji beda dari rata-rata kelompok. Dalam desain penelitian eksperimen yang menggunakan statitstical completely randomized design, ANOVA merupakan alat analysis yang paling tepat ketika kondisi dari randomisasi dan replikasi terpenuhi (Zikmund, 2003:282).

\section{Hasil dan Pembahasan}

\section{Karakteristik Partisipan}

Dalam penelitian eksperimen yang sesungguhnya, jumlah partisipan adalah 100 orang yang terdiri dari 50 partisipan kelompok eksperimen pertama dengan perlakuan berupa iklan dengan endorser selebriti nasional, dan 50 partisipan untuk kelompok eksperimen kedua dengan perlakuan berupa iklan dengan endoserselebriti global. Untuk menguji homogenitas dari karakteristik partisipan penelitian berdasarkan jenis kelamin dan usia pada dua kelompok perlakuan, digunakan uji ChiSquare. Dari hasil pengolahan data proporsi jenis kelamin, diperoleh hasil Asymp.sig $=0,841$ dengan nilai probabilitas $>0,05$, yang berarti bahwa tidak terdapat perbedaan proporsi antara pria dan wanita pada dua kelompok perlakuan (homogen). Untuk pengolahan data berdasarkan proporsi usia, diperoleh hasil Asymp.sig $=0,072$ yang berarti bahwa tidak terdapat perbedaan proporsi antara kelompok usia 18-20 tahun dan kelompok usia 21-23 tahun pada dua kelompok eksperimen (homogen). Berdasarkan uji homogenitas keseluruhan terhadap proporsi jenis kelamin dan usia, maka dapat disimpulkan bahwa pada dua kelompok perlakuan dalam eksperimen memiliki karakteristik partisipan yang sama, terbukti dari nilai Chi-Square yang menunjukkan nilai probabilitas, baik jenis kelamin maupun usia, yang lebih dari 0,05. Hal ini berarti bahwa sikap partisipan pada saat merespon iklan adalah sikap yang diperoleh karena adanya perlakuan pada saat eksperimen, bukan disebabkan karena 
adanya perbedaan pada karakteristik partisipan. Karakteristik demografi partisipan dan hasil uji homogenitas dari karakteristik tersebut disajikan dalam Tabel 1.

Uji Validitas dan Reliablitas

Dalam penelitian eksperimen terdapat dua jenis validitas yaitu validitas internal (menunjukkan derajat kepercayaan dalam efek hubungan kausal yang artinya variabel independen dapat berdampak pada variabel dependen) dan validitas eksternal (menunjukkan tingkat generalizability dari hasil suatu studi kausal pada setting orang atau peristiwa yang lain). Dalam penelitian ini, validitas internal dihasilkan dengan mengontrol exogenous variables dengan menggunakan randomisasi pada pemilihan partisipan penelitian. Validitas eksternal dihasilkan dengan menggunakan eksperimen laboratorium between subject dimana pada kedua level perlakuan yang diberikan dalam eksperimen, tiap kelompok eksperimen hanya mendapatkan satu level perlakuan saja, yaitu iklan dengan endorserselebriti nasional (kelompok eksperimen 1) atau iklan dengan endorser selebriti global (kelompok eksperimen 2). Peneliti juga melakukan uji validitas berdasarkan confirmatory factor analysis untuk menguji apakah suatu konstruk memiliki unidimensionalitas yang menunjukkan apakah indikator-indikator yang digunakan dapat mengkonfirmasi sebuah konstruk atau variabel. Hasil uji validitas menunjukkan nilai Kaiser-MeyerOlkin Measure of Sampling Adequacy sebesar 0,634 (> 0,50), sedangkan nilai Bartlett's Test of Sphericity dengan nilai Chi-Square sebesar 227,134 dan signifikansi 0,000 yang berarti bahwa uji analisis faktor dapat dilanjutkan. Berdasarkan pengolahan data dengan analisis faktor, hasil rotasi faktor dengan metode varimax menunjukkan bahwa seluruh item pengukuran atau indikator dari variabel sikap terhadap iklan ( $\mathrm{AAd}$ ), sikap terhadap merek ( $\mathrm{ABr}$ ), dan niat membeli $(\mathrm{PI})$ memiliki nilai factor loading > 0,4. Indikator sikap terhadap iklan (AAd) mengelompok pada faktor 1, indikator sikap terhadap merek ( $\mathrm{ABr}$ ) mengelompok pada faktor 2, dan indikator niat membeli (PI) mengelompok pada faktor 3 , seperti yang disajikan dalam tabel 1 . Sesuai hasil rotasi faktor pada tabel 1 tersebut, maka dapat disimpulkan bahwa semua indikator yang digunakan di masing-masing variabel dependen dalam penelitian ini sudah valid. 
Tabel 1. Karakteristik Demografi Partisipan dan Uji Homogenitas

\begin{tabular}{cccccc}
\hline $\begin{array}{c}\text { Karakteristik } \\
\text { Demografi }\end{array}$ & $\begin{array}{c}\text { Kelompok } \\
\text { Eksperimen } \\
\text { Pertama }\end{array}$ & $\begin{array}{c}\text { Kelompok } \\
\text { Eksperimen } \\
\text { Kedua }\end{array}$ & $\begin{array}{c}\text { Chi-Square } \\
\text { Test }\end{array}$ & $\begin{array}{c}\text { Asymp. } \\
\text { Sig }\end{array}$ & Keterangan \\
\hline Gender: Wanita & 27 & 24 & 0,040 & 0,841 & Homogen \\
Pria & 23 & 26 & & & \\
Usia: 18-20 tahun & 36 & 35 & 3,240 & 0,072 & Homogen \\
21-23 tahun & 14 & 15 & & & \\
\hline
\end{tabular}

Sumber: data diolah, 2018

Tabel 2. Hasil Uji Validitas dan Reliabilitas

\begin{tabular}{cccc}
\hline & Factor & \multicolumn{2}{c}{ Cronbach's Alpha } \\
\cline { 3 - 4 } & Loading & $\begin{array}{c}\text { Endorser Selebriti } \\
\text { Nasional }\end{array}$ & $\begin{array}{c}\text { Endorser Selebriti } \\
\text { Global }\end{array}$ \\
\hline Sikap terhadap Iklan (AAd): & 0,898 & 0,775 & 0,694 \\
AAd1 & 0,838 & & \\
AAd2 & 0,741 & & 0,709 \\
AAd3 & 0,816 & 0,654 & \\
Sikap terhadap Merek (ABr): & & & \\
ABr1 & 0,769 & & 0,792 \\
ABr2 & 0,726 & & \\
ABr3 & & & \\
Niat Membeli (PI): & 0,866 & 0,785 & \\
Pl1 & 0,900 & & \\
PI1 & & &
\end{tabular}

Sumber: data diolah, 2018

Hasil uji reliabilitas untuk eksperimen menunjukkan bahwa nilai Cronbach's Alpha dari masing-masing variabel dependen untuk iklan dengan endorser selebriti nasional dan iklan dengan endorser selebriti global sudah cukup baik atau reliabel, yang nilainya > 0,60, sehingga dapat digunakan untuk pengujian selanjutnya. Koefisien reliabilitas dengan nilai Cronbach's Alpha antara 0.60 - 0.70 sudah cukup baik dan dapat diterima (Hair et al. 2006:92). Hasil uji validitas dan reliabililtas disajikan di Tabel 2.

\section{Uji Hipotesis}

Dalam pengujian hipotesis penelitian yang menggunakan ANOVA, salah satu asumsi yang harus dipenuhi adalah homogeneity of variance yang menunjukkan bahwa variabel dependen harus memiliki varians yang sama dalam setiap kategori variabel independen. Hasil uji homogeneity of variance ditampilkan dalam Tabel 3. Berdasarkan Tabel 3, terlihat bahwa nilai levene test untuk variabel sikap terhadap iklan adalah 1,645 dengan nilai probabilitas 0,203 , untuk variabel sikap terhadap merek nilaianya adalah 0,474 dengan nilai probabilitas 0,493 , dan nilai levene test untuk variabel niat membeli adalah 0,495 dengan nilai probabilitas 0,483 . Semua nilai signifikansi nenunjukkan hasil yang lebih besar dari level signifikansi (probabilitas > 
0,05) maka dapat disimpulkan bahwa varians dalam kelompok adalah sama dan pengujian ANOVA dengan menggunakan uji $F$ dapat dilakukan.

Tabel 3. Hasil Uji Homogeneity of Variance

\begin{tabular}{ccccc}
\hline Variabel & Levene Statistic & df1 & df 2 & Sig. \\
\hline Sikap terhadap Iklan $(\mathrm{AAd})$ & 1,645 & 1 & 98 & 0,203 \\
Sikap terhadap Merek $(\mathrm{ABr})$ & 0,474 & 1 & 98 & 0,493 \\
Niat Membeli $(\mathrm{PI})$ & 0,495 & 1 & 98 & 0,483 \\
\hline
\end{tabular}

Sumber: data diolah, 2018

Dalam penelitian ini, ada tiga hipotesis yang diajukan. Hipotesis 1 bertujuan untuk menguji apakah iklan yang menggunakan endorser selebriti nasional lebih berpengaruh positif terhadap sikap konsumen terhadap iklan jika dibandingkan dengan iklan yang menggunakan endorser selebriti global. Hasil analisis ANOVA mengindikasikan bahwa terdapat perbedaan yang signifikan antara dua kelompok perlakuan, yaitu iklan dengan endorser selebriti nasional dan iklan dengan endorser selebriti global, pada variabel sikap terhadap iklan (mean untuk endorser selebriti nasional $=4,90$, mean untuk endorser selebriti global $=4,15, \mathrm{~F}$ output $=28,333$ ). Nilai $\alpha$ yang diperoleh dari hasil uji ANOVA adalah $0,000(\alpha<0,005)$ yang menunjukkan bahwa hipotesis 1 yang menduga adanya pengaruh yang lebih positif dari iklan dengan endorser selebriti nasional dibandingkan dengan iklan dengan endorser selebriti global pada sikap konsumen terhadap iklan didukung. Hal ini berarti bahwa iklan yang menggunakan endorser selebriti nasional lebih berpengaruh positif pada sikap konsumen terhadap iklan dibandingkan dengan iklan yang menggunakan endorser selebriti global. Hasil penelitian yang dilakukan oleh Jain et al. (2010) juga menunjukkan bahwa penggunaan endorser selebriti nasional dalam iklan lebih berpengaruh positif pada sikap konsumen terhadap iklan, namun penelitian tersebut membandingkan antara endorser selebriti nasional dan endoser selebriti regional dalam iklan. Penggunaan selebriti sebagai endorser dalam iklan terbukti efektif mempengaruhi sikap konsumen terhadap iklan sesuai dengan penelitian yang dilakukan oleh Liu et al. (2007) dan Pughazhendi et al. (2011).

Hipotesis 2 dalam penelitian ini bertujuan untuk menguji apakah iklan yang menggunakan endorser selebriti nasional lebih berpengaruh positif terhadap sikap konsumen terhadap merek jika dibandingkan dengan iklan yang menggunakan endorser selebriti global. Berdasarkan Tabel 4, hasil analisis ANOVA mengindikasikan bahwa terdapat perbedaan yang signifikan antara dua kelompok perlakuan, yaitu iklan dengan endorser selebriti nasional dan iklan dengan endorser 
selebriti global, pada variabel sikap terhadap merek (mean untuk endorser selebriti nasional $=4,75$, mean untuk endorser selebriti global $=4,58, F$ output $=1,573$ ). Nilai $\alpha$ yang diperoleh dari hasil uji ANOVA adalah $0,213(\alpha>0,005)$ yang menunjukkan bahwa meskipun terdapat perbedaan nilai mean antara iklan dengan endorser selebriti nasional dan endorser selebriti global, namun ternyata penggunaan endorser selebriti nasional maupun global dalam iklan sama-sama tidak berpengaruh positif pada sikap konsumen terhadap merek, yang berarti bahwa hipotesis 2 dalam penelitian ini tidak didukung.

Hipotesis 3 dalam penelitian ini bertujuan untuk menguji apakah iklan yang menggunakan endorser selebriti nasional lebih berpengaruh positif terhadap niat membeli konsumen jika dibandingkan dengan iklan yang menggunakan endorser selebriti global. Hasil analisis ANOVA mengindikasikan bahwa terdapat perbedaan yang signifikan antara dua kelompok perlakuan, yaitu iklan dengan endorser selebriti nasional dan iklan dengan endorser selebriti global, pada variabel niat membeli (mean untuk endorser selebriti nasional $=4,25$, mean untuk endorser selebriti global $=3,76$, F output $=4,773)$. Nilai $\alpha$ yang diperoleh dari hasil uji ANOVA adalah 0,031 $(\alpha>0,005)$ yang menunjukkan bahwa meskipun terdapat perbedaan nilai mean antara iklan dengan endorser selebriti nasional dan endorser selebriti global, namun ternyata penggunaan endorser selebriti nasional maupun global dalam iklan sama-sama tidak berpengaruh pada niat membeli konsumen terhadap produk yang diiklankan, yang berarti bahwa hipotesis 2 dalam penelitian ini tidak didukung. Hal ini sesuai dengan hasil penelitian sebelumnya yang dilakukan oleh Jain et al. (2010), O'Mahony dan Meenaghan (1997/1998), Ranjbarian et al. (2010), yang mengemukakan bahwa penggunaan selebriti sebagai endorser dalam iklan tidak efektif mempengaruhi niat beli konsumen terhadap produk yang diiklankan tersebut.

Tabel 4. Hasil Uji One-Way ANOVA

\begin{tabular}{|c|c|c|c|c|c|c|c|c|}
\hline & \multicolumn{2}{|c|}{$\begin{array}{c}\text { Endorser Selebriti } \\
\text { Nasional }\end{array}$} & \multicolumn{2}{|c|}{$\begin{array}{c}\text { Endorser Selebriti } \\
\text { Global }\end{array}$} & \multirow{2}{*}{$\mathbf{N}$} & \multirow[b]{2}{*}{ df } & \multirow[b]{2}{*}{$\mathbf{F}$} & \multirow[b]{2}{*}{ Sig. } \\
\hline & Mean & $\begin{array}{l}\text { Standar } \\
\text { Deviasi }\end{array}$ & Mean & $\begin{array}{l}\text { Standar } \\
\text { Deviasi }\end{array}$ & & & & \\
\hline AAd & 4,9000 & 0,71743 & 4,1534 & 0,80915 & 100 & 1 & 23,833 & 0,000 \\
\hline $\mathrm{ABr}$ & 4,7532 & 0,70591 & 4,5802 & 0,67293 & & 1 & 1,573 & 0,213 \\
\hline $\mathrm{PI}$ & 4,2500 & 1,11689 & 3,7600 & 1,12595 & & 1 & 4,773 & 0,031 \\
\hline
\end{tabular}




\section{Kesimpulan}

Berdasarkan hasil pengujian hipotesis secara keseluruhan, penggunaan endoser selebriti nasional dan endorser selebriti global dalam iklan, khususnya untuk jenis produk dengan tingkat keterlibatan yang rendah, terbukti efektif mempengaruhi sikap konsumen terhadap iklan, tapi tidak untuk sikap konsumen terhadap merek, dan niat membeli. Penggunaan endorser selebriti nasional ternyata lebih berpengaruh positif pada sikap konsumen terhadap iklan jika dibandingkan penggunaan endoser selebriti global. Penelitian yang dilakukan oleh Jain et al. (2010) juga membuktikan bahwa penggunaan endorser selebriti nasional lebih berpengaruh positif pada sikap konsumen terhadap iklan, khususnya untuk produk dengan tingkat keterlibatan yang rendah, namun jika dibandingkan dengan penggunaan endorser selebriti regional dalam iklan. Hasil dari penelitian ini menunjukkan bahwa penggunaan selebriti sebagai endorser terbukti efektif dalam periklanan sebagai salah satu tekhnik yang paling populer dalam upaya mengkomunikasikan produk ke konsumen.

Penggunaan endorser selebriti dalam iklan terbukti efektif mempengaruhi sikap konsumen terhadap iklan sehingga meskipun perusahaan harus mengeluarkan biaya yang tidak sedikit untuk merekrut para selebriti tersebut, namun hal ini akan berpengaruh positif terhadap efektivitas iklan sebagai bagian dari komunikasi pemasaran. Pemilihan selebriti untuk iklan yang akan dipromosikan khususnya dalam skala nasional sebaiknya menggunakan endorser selebriti nasional saja karena terbukti lebih efektif daripada harus menggunakan selebriti global yang tentunya akan ada perbedaan biaya yang cukup signifikan antara kedua selebriti tersebut, dimana biaya perekrutan selebriti global dinilai lebih tinggi jika dibandingkan dengan biaya perekrutan selebriti nasional.

\section{Saran}

Penelitian ini menggunakan iklan cetak. Penelitian eksperimen juga dapat dilakukan dengan menggunakan iklan televisi yang mungkin akan memiliki pengaruh yang berbeda pada sikap konsumen. Selain itu, penelitian ini hanya difokuskan pada satu merek produk saja dalam kategori tingkat keterlibatan yang rendah, khususnya untuk consumer goods, sehingga hasilnya tidak dapat digeneralisasikan secara umum. Penelitian ini dapat direplikasi dengan partisipan yang berasal dari lingkungan luar kampus atau non-mahasiswa untuk memastikan apakah penemuan dalam penelitian ini bisa digeneralisasi pada masyarakat umum lainnya. Penelitian ini juga tidak membedakan selebriti dan partisipan berdasarkan jenis kelamin, padahal 
mungkin akan terdapat perbedaan dalam sikap konsumen pria dan wanita ketika merespon iklan yang menggunakan endorser selebriti pria atau wanita.

\section{Daftar Referensi}

Aaker, D. A., Kumar, V., Day, G. S., and Leone, R. P. 2011. Marketing Research, 10th ed. Hoboken, NJ: John Wiley \& Sons, Inc.

Alsmadi, S. 2006. The power of celebrity endorsement in brand choice behavior: an empirical study of consumer attitudes in Jordan, Journal of Accounting - Business and Management, 13: 69-84.

Assael, H. 2001. Consumer Behavior and Marketing Action, 6th ed. Singapore: Thomson Learning Pte, Ltd.

Droge, C. 1989. Shaping the route to attitude change: central versus peripheral processing through comparative versus non comparative advertising. Journal of Marketing Research, 26 (2) (May): 193-204.

Friedman, H. H., S. Termini., and R. Washington. 1976. The effectiveness of advertisements utilizing four types of endorsers. Journal of Advertising, 5 (3) (Summer): 22-24.

Hakimi, Y.B., Abedniya, A., and Zaeim, M, N. 2011. Investigate the impact of celebrity endorsement on brand image. European Journal of Scientific Research, 58, (1): 116-132.

Jain, V., Roy, S., Kumar, A., and Kabra, A. 2010. Differential effect of national vs. regional celebrities on consumer attitudes. Management \& Marketing Challenges for Knowledge Society, 5 (4): 121-134.

Liu, M. T., Huang, Y., and Minghua, F. 2007. Relations among attractiveness of endorsers, match-up, and purchase intention in sport marketing in China. Journal of Consumer Marketing, 24 (6): 358-365.

Kamins, M. A. 1990. An investigation into the "match-up hypothesis" in celebrity advertising: when beauty may be only skin deep. Journal of Advertising, 19 (1): 413.

Mackenzie, S. B., Lutz, R. T., and Belch, G. E. 1986. The role of attitude toward the ad as a mediator of advertising effectiveness: a test of competing explanations. Journal of Marketing Research, 23 (2): 130-143.

McCracken, G. 1989. Who is celebrity endorser? Cultural foundations of the endorsement process. Journal of Consumer Research, 16 (3): 310-321.

Mehta, A. 1994. How advertising response modeling (ARM) can increase ad effectiveness. Journal of Advertising Research, (May/June): 62-74.

Nelson, O. 2010. Celebrity advertising and its effectiveness on brand loyalty. Interdisciplinary Journal of Contemporary Research in Business, 1 (9): 70-87.

Peter, J. P. and Olson, J. C. 2001. Consumer Behavior and Marketing Strategy, 6th ed. New York: McGraw-Hill//rwin. 
Petty, R. E., Cacioppo, J. T., and Schumann, D. 1983. Central and peripheral routes to advertising effectiveness: the moderating role of involvement. Journal of Consumer Research, 10: 135-146.

Pughazhendi A., Thirunavukkarasu R., and Susendiran, S. 2011. A Study on Celebrity Based Advertisements on the Purchase Attitude of Consumers towards Durable Products in Coimbatore City, Tamil Nadu, India. Far East Journal of Marketing and Management, Vol. 1(3), (December): 16-27.

Ranjbarian, B., Z. Shekarchizade., and Z. Momeni. 2010. Celebrity endorser influence on attitude toward advertisements and brands. European Journal of Social Sciences, 13 (3): 399-407.

Sekaran, U. and R. Bougie. 2010. Research Methods for Business, A Skill Building Approach, 5th ed. Chichester, WS: John Wiley \& Sons, Ltd.

Seno, D. and Lukas, B. A. 2007. The equity effect of product endorsement by celebrities. European Journal of Marketing, 41 (1/2): 121-134.

Silvera, D. H and Austad, B. 2004. Factors predicting the effectiveness of celebrity endorserment advertisement. European Journal of Marketing, 38 (11/12): 15091526.

Till, B. D and Busler, M. 1998. Matching products with endorsers: attractiveness versus expertise," Journal of Consumer Marketing, 15 (6): 576-586.

Zikmund, W. G. 2003. Business Research Methods, 7th ed. Mason, Ohio: Thomson, South-Western. 